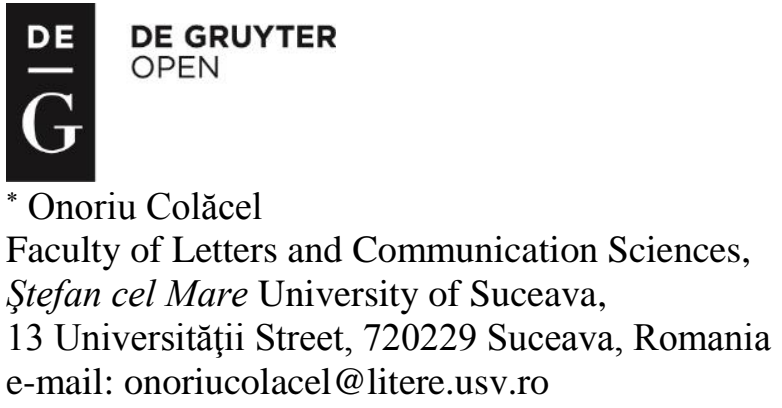

\title{
TEACHING THE NATION: LITERATURE AND HISTORY IN TEACHING ENGLISH
}

\begin{abstract}
Teaching English as a foreign language is rooted in the national interest of English-speaking countries that promote their own culture throughout the world. To some extent, 'culture' is a byword for what has come to be known as the modern nation. Mainly the UK and the US are in the spotlight of EFL teaching and learning. At the expense of other, less 'sought-after' varieties of English, British and American English make the case for British and American cultures. Essentially, this is all about Britishness and Americanness, as the very name of the English variety testifies to the British or the American standard. Of course, the other choice, i.e. not to make a choice, is a statement on its own. One way or another, the attempt to pick and choose shapes teaching and learning EFL. However, English is associated with teaching cultural diversity more than other prestige languages. Despite the fact that its status has everything to do with the colonial empire of Great Britain, English highlights the conflict between the use made of the mother tongue to stereotype the non-native speaker of English and current AngloAmerican multiculturalism. Effectively, language-use is supposed to shed light on the self-identification patterns that run deep in the literary culture of the nation. Content and language integrated learning (CLIL) encompasses the above-mentioned and, if possible, everything else from the popular culture of the English-speaking world. It feels safe to say that the intractable issue of "language teaching as political action" (Cook, 2016: 228) has yet to be resolved in the classrooms of the Romanian public schools too.
\end{abstract}

Keywords: EFL teaching, CLIL, mother tongue, national culture

\section{Teaching your nation versus teaching about the nation}

Fictional and real-life stories in the teaching of English have always contributed to a multitude of learning opportunities. However, literature and history have already convinced many teachers that they are not worth the trouble. The two of them seem to enjoy the same level of cultural prestige, or insignificance for that matter, in EFL teaching. Considering that most canonical literary texts are read against the backdrop of historical events, for the purposes of this study I focus on the use-value of literature and history in the English class. I assume that learning English through stories, be they literary or historical, is always in the background of language learning. Factually, reading and listening comprehension skills are developed in connection with narrative texts that are a staple of many EFL classes.

The approach to notions of literacy and exploration is commonly thought to fall into three major theories of learning. The transmission theory: "acquiring facts and knowledge" (Beach, Appleman, Hynds, Wilhelm, 2001: 6); "the teacher as the centre of instruction" (Idem: 7); student-centred theory: pupils rather than teachers "make their own choices for what and how they would learn" (Ibidem); socio-cultural learning theory: students "learn to acquire uses of certain practices and tools that serve certain purposes" (Idem: 9) in their society; teachers should be able to help create "a social community that supports learning literature" (Ibidem).

\footnotetext{
* Dr Onoriu Colăcel is Lecturer in English at the Ștefan cel Mare University of Suceava, Romania. His work focuses on contemporary English literature and patterns of self-identification in literature and popular culture.
} 
The latest developments in English language teaching methodology are a setback particularly for the world-wide study of the English-speaking countries' literature and history. A canon of loosely connected stories about momentous events in the past of the UK/US, recorded in the language of literature and history, loses lustre in favour of more common pursuits that have to do with popular forms of present-day visual culture. The many narratives of an Anglo-American pop culture increasingly make their way into the classroom as if to show that developing a highbrow cultural taste among the students of English is not the pursuit of public schools anymore. However, I find that the notions of cultural competence fostered by schools look back at "the rhetorical roots of English studies [...] the medieval trivium - grammar, rhetoric, and dialectic" (Scholes, 2011), which have always been asked to build the citizens of tomorrow. Comprehension tasks build on compare-and-contrast activities as a means of producing spoken and written language.

My aim here is to advance the understanding of how teachers choose to rely on the literary culture (i.e. canonical literary and historical texts) of the nation whose language they teach. Despite the need to defend reading skills in formal education (Schwarz, 2008), the written language of books is resilient enough to withstand the challenge of the IT age, specifically its impact on written language. Hopefully, a mixed research method helps me bring out the response of teachers to the course books as well as to the various teaching resources that advise an English only policy in the EFL class. Reading some of the above-mentioned textbooks and interviewing a sample of 40 English teachers should give some insight into what is going on in the Romanian public schools North of the country.

The case against using literature in the classroom has long been spoken of. It is an example of an expected paradigm shift in English studies (Scholes, 1999). The ongoing debate on didactic approaches to teaching literary texts proves that education based on highbrow culture has increasingly come under criticism (Hinnov, Harris, Rosenblum, 2013). For a long time now, 'English Studies' seems to be at a crossroad. Everything happened following the advent of the new media and digital humanities. Ever since, the way out from the dilemma posed by the case of literature and history in teaching English has been to "move on from literature, narrowly defined, to textuality - a looser, broader concept that opens a direction toward a viable future" (Scholes, 2011: 230).

There is no doubt that historians and readers in humanities have long lived with the fact that progress in language learning is not necessarily linked to reading stories. Knowing about the culture that originated the language learned in formal schooling is not a must either, not to mention that, for instance, English for specific purposes mostly disregards what the above mentioned professionals deem to be the treasure trove of humankind. Yet, the practice of teaching English is informed by strong awareness of the world the native speakers live in. Speaking 'proper' English has everything to do with identifying them and what they have to say about it (as the exams that award certificates in English language teaching prove). Exclusively the British or the American native speaker can give insight into key cultural issues 'required' for an effective learning experience:

The role of the language teacher as a carrier of cultural messages is central to certain understandings of language teaching. Implicit in the concept is that the culture and values that underpin a language cannot be divorced from the language itself, and that an appreciation of certain key cultural concepts are required for a true understanding of the language being learnt. It may be that this idea, especially when related to English, has a limited life span. (O'Connell, 2009: 11)

The very name of the native speakers, who can boast some measure of competence in English teaching, conjures up a mythical status around the classrooms of the world. Allegedly, the British or the American teacher of English elicits positive feedback from students inasmuch as the young learners benefit from an authentic instruction environment. The native comes across as a teaching resource whose 'limited life span' is due to the sheer number of cheaper non-native teachers. Except for the economics behind teaching English, it seems that all teachers are expected to identify themselves as nationals of one country or another while at work. The quotation above makes the same point. It recalls the long-standing question of whether the British Council or "its paymasters had a master plan for extending ELT, and through it, maintaining British influence worldwide" (Phillipson, 1992: 300). According to those in charge of "English teaching operations" (Ibidem), the answer is 'no'. There is no doubt that the British Council pulled off a successful 'operation' that resulted in the rise of British 
English Studies throughout Eastern Europe after the fall of the communist bloc. In spite of that, the British Council is said to have nothing to do with politics ${ }^{1}$. However, this is a tentative answer. Possibly, it is an educated guess about the outcome of British involvement with the politics of language in an area of Europe that traditionally had as a lingua franca French or German. English teaching gained momentum at the beginning of the 1990s, effectively replacing French as the first foreign language in Romanian public schools. Russian, which used to be compulsory in the first decades of the communist Romania, had already lost its position throughout the years of Nicolae Ceaușescu's regime. As often the case with education and politics, there is more than one side to the story. Much like with French, German and Russian, the study of English makes a statement about the pupils' mother tongue, namely, "when the professionalism of ELT is essentially Anglocentric, $[\ldots]$ there is almost inevitably a linguicist devaluing of local languages and cultures" (Idem: 306). Still, the social benefits of learning a prestigious foreign language are plain to see for most parents of children who get to learn English in Romanian schools.

The opposing points of view have already persisted for a long time and there is no doubt that they are here to stay. Big differences over the place of principles in everyday teaching practice shape class management. Those who suspect that the teaching of prestige languages may contribute to a change in national self-awareness do not see reason enough to change their mind. Those on the other side of the fence argue that there is really nothing to worry about. Conclusively, it feels safe to say that the teachers and students of English face an intractable issue.

A modern "world of nations" (Billig, 1995: 14), one that is said to have emerged with the French revolution of 1789, provides the backdrop of language learning and teaching. Teaching your nation versus teaching about somebody else's nation is a choice that comes with the territory of the public funded learning of foreign languages. In the state-run schools of the nation, teaching and learning English, Russian or French entail some unspoken conjectures about the relation between the concerned parties. What happens is that, instead of sticking to language teaching, most teachers rely on the literary and, lately, on the popular culture of the nation whose language they teach. In order to reach the pupils, compare-and-contrast activities bring to their attention their own culture as a yardstick to measure their learning progress.

When it comes to teaching the nation, finding out what it is like to belong to a nation is the big question. Most of the times, the assessment of language skills helps with deciding who is in and who is out. Both the native and the second language are treated on the basis of equality, yet the prestige culture of the latter is never actually questioned. Bilingual (or more than bilingual) education is embedded in the tradition of teaching your people about the ethnic other, commonly about the world of the nation states that teachers and students inhabit. Essentially, the long history of the textbook genre throughout the world has everything to do with teaching your people who they are.

The culture of the nation is at the heart of teaching English as a foreign language. Culture is a byword for what has come to be known as the modern nation. Mainly the UK and the US are in the spotlight of EFL teaching and learning, which helps teachers to use the contrast for didactic effect. At the expense of other, less 'sought-after' varieties of English, British and American English make the case for nothing else but the British and the American culture. To some extent, teaching and learning are all about Britishness and Americanness, as the very name of the English language standard testifies to. Of course, the choice not to make a choice is always available, yet it comes across as a statement on its own. The attempt to pick and choose shapes the approach to foreign languages in Romanian public schools too. Particularly English is associated with cultural diversity and the multiculturalism of the EU. Despite the fact that its status has everything to do with the colonial empire of Great Britain, English highlights two conflicting opinions about the varied cultural and ethnic groups of the UK and the US. Namely, the use made of language in order to stereotype the other as opposed to the linguistic legacy of various ideologies ${ }^{2}$ whose impact can be traced across the $20^{\text {th }}$ century. Effectively, language-use is supposed to replace national self-identification patterns that run deep in the literary culture (literature, history, authentic materials) commonly employed as teaching aids in EFL classes. As it is the case with

\footnotetext{
${ }^{1}$ The curriculum of the English study programme of the Stefan cel Mare University of Suceava is proof of the support lent by the Romanian branch of British Council prior to Romania's accession to the European Union.

${ }^{2}$ For example, various state enforced equal-opportunities policies.
} 
all non-native speakers of English, it feels safe to say that this is an intractable issue, which has yet to be resolved by the Romanian teachers of English.

My primary sources ${ }^{3}$ are secondary school textbooks. They are global course books, i.e. not tailored for the needs of a particular market, and even less so for the Romanian one. They fall into three categories: literature-related textbooks, history-related textbooks and, last but not least, English language teaching (ELT) textbooks that have sections devoted to "content and language integrated learning' (hereafter CLIL).

In the mainstream of English studies, educators and academics increasingly scrutinize the evidence of systemic failure in the industry of English teaching. "Many ELT materials (especially global coursebooks) currently make a significant contribution to the failure of many learners of English as a second, foreign or other language to even acquire basic competence in English and to the failure of most of them to develop the ability to use it successfully" (Tomlinson, 2008: 3). There are many possible reasons why such an appraisal is timely. However, I am going to approach the issue in Romanian public schools, from the angle of what is currently known as nationalism studies. I assume that the textbook genre makes a significant contribution to enhancing the students' understanding of their own nation and culture. Knowledge about contrasts between 'us' and 'them' (political institutions, history, and literature) is firmly in place in the practice of teaching foreign languages, irrespective of failure or success in acquiring basic language competence. Notions of 'consistency' and 'consensus' define the framework that keeps in check the potential for political engagement of literature and history, i.e. of (national) culture. Most of the times, these schoolbooks help understand teaching prestige foreign languages "as the degree of social uniformity produced by the imposition of culture [...] by one set of people on another (Archer, 1996: 4). They make the point that your nation (of the teacher as well as of the student) is the benchmark against which teaching the native language of the other takes place. There is also something about the culture of the nation whose mother tongue you learn/teach that makes it worthy of discussion.

Finally, working towards linking culture with practical strategies for teaching language under the challenging conditions of classroom environments resulted in CLIL.

\section{Highbrow and Popular Culture in the Classroom}

For practical reasons, certain easy to follow instructions are popular with teachers and students alike. Ultimately, the assessment of integrated learning examines the effectiveness of teaching English through content. Considering that communicating knowledge in classrooms is a value-laden task, the assessment of the learning outcome is likely to give a clue about the impact of British or American culture on English students. In all likelihood, the "pre-use, while-use and post-use evaluation" (Masuhara \& Tomlinson, 2008) are likely to give insight into the place and function of the nation in the textbook genre. The long history of general English course books makes a virtue out of the necessity of switching between the source and target language, as entailed by translation. The status enjoyed by the so-called classical languages across the Western world for centuries, i.e. by Latin and Greek, would appear to resemble that of English nowadays. It turns out that it is not the case, according to CLIL practitioners:

In fact, being educated in a prestigious foreign language has been the prerogative of elite education at prestigious institutions for centuries. An essential difference of present-day CLIL, therefore, is the fact that it is rooted within mainstream education [...]. It cannot be denied though that a lingering flavour of elitism has most likely contributed to the enthusiastic acceptance of CLIL by parents (and some students), in particular as regards being instructed through English, whose status

\footnotetext{
${ }^{3}$ Ronder, D., Thompson, P. 2012. Past Simple. Learning English through History, Reading: Garnet Education; Brodey, K. 2007. A Concise History of Britain from its Beginnings to The Present Day, Recanati: ELI - Modern languages; Evans, V., Dooley, J. 2014. Pathways to Literature, Teacher's Book, Newbury: Express Publishing; Allen, D. R., Roberts, R. J., Tierney, J., Whiteside, G., Wrenn. C., Malgaretti, F. G. 2003. Words Words Words. A History and Anthology of Literatures in English. The $20^{\text {th }}$ Century Literatures in English, Milan: La Spiga languages; Bentley, K. 2010. The TKT Teaching Knowledge Test Course CLIL Module Content and Language Integrated Module, Cambridge: Cambridge University Press.
} 
is high given its prominence as the de facto international language of today. (Dalton-Puffer, Nikula \& Smit, 2010: 3)

However, there is no way around the contrastive approach to teaching English in a bilingual environment, which is inherent to content and language integrated language. The classical languages and the modern prestige ones make sense to students by means of translating meanings into the mother tongues of learners, particularly, of young learners. Irrespective of whatever the English-speaking civilization has to offer, sooner or later the students' own culture and language kick in. As they learn English, the exchange between the foreign and the native language helps them realize the meanings of both of them. They come to associate the foreign language with the prestige one, while their own is subject to constant improvement by word loans and Anglicisms. Specifically, highbrow and popular culture are at play in the introduction of English idioms into Romanian sentences.

In fact, the intractable choice of which language to use in order to teach the other language has always been around for teachers. "Communication and culture are elusive terms. Thus, when we bind and extend them to produce intercultural communication, we are doing ourselves and others a disservice unless we offer a reasonable explanation of what the terms signify, how they are manifest in modern educational systems and approaches" (Marsh, 2009: 12). The words of the academic who coined CLIL give depth to the findings of others who point out that, for most teachers, integrated content learning is "an 'umbrella' term used to talk about bilingual education situations" (Gajo, 2007 as quoted in Bentley, 2010: 5). Importantly, the use of the other language (i.e. not the CLIL language) is undesirable. Only "less able learners can be given dual language texts or labels which have words written in both the native language and the CLIL language" (Bentley, 2010: 80).

Pre-use and post-use evaluation stand out as means to assess the way teaching EFL through culture impacts on the worldview of students of English. Prior and after they are exposed to integrated English and content learning, "the actual effects of materials on users" (Tomlinson, 2003: 25), as well as their absence, can be measured. Whether or not while-use evaluation might be of any help is a question to be asked. The increasingly influential CLIL approach to teaching in English textbooks and the history/the literature-related textbooks might help with the answer.

\subsection{History-related textbooks}

There is wide consensus that the use of another language than English in the EFL class is more or less undesirable, if not to be avoided (Hedge, 2000; Thornbury, 2006; Harmer, 2007). As a matter of good practice, "students need the experience of uninterrupted, meaningful communication if they are to learn to use the language" (Edge, 1989: 37). Obviously, the only language expected to be in use is English: "the student's native tongue is used in class until the student learns English" (Spring, 2016: 198).

By comparison with literature-related schoolbooks and CLIL resources, the textbooks that focus on history as a medium for instruction are distinctly more 'faithful' to their academic discipline, both in form and content. History textbooks show that history is the battlefield where historians fight over the cultural transmission of their nation's past. Accordingly, history teaching "is an 'issue-based' concept" (Phillips, 2000: 10) whose meanings and form the modern nation states have always been eager to regulate. Even if they were to be a means to some other end than nation building (i.e. learning English), history taught in EFL classes needs the stamp of approval of more than one state. Although one of them boasts the subtitle of "Modern Languages" on the front cover (Brodey, 2007), The Concise History of Britain (hereafter $C H B$ ) is a chronological and nation-centred narrative that is not far from a full-fledged history book. The other one, Learning English through History, is neatly divided into chronological and thematic chapters. However, both of them are based on a telling of history that pumps up the prestige of English civilization. Basically, King Henry VIII, Queen Elizabeth I, or Margaret Thatcher of the former half of the text pave the way for developing thematic chapters that give insight into the consequences of their deeds in the recent history of Great Britain. Their point of view is unapologetically English. Here are two self-explanatory titles: "A funny old game: Cricket" (Ronder \& Thompson, 2012: 102-107) and "That cloud in the West: Ireland" (Ronder \& Thompson, 2012: 120125). As for Kenneth Brodey's schoolbook, the students of English find out more about the time 
"England Becomes a Nation" (Brodey, 2007: 22-29), or about the "Tudor England and the Consolidation of the Nation State" (Brodey, 2007: 30-41), etc.

The above-mentioned textbooks are furthest possible things from what one would expect to happen in a bilingual setting. Considering that "CLIL classrooms, [are] often also called Bilingual Education" (Heine, 2010: 2), code switching between two languages (most of the times, the 'universal' one of the pair is English) is conceptually entailed by teaching culture as difference. The fact that "language learning is assumed to take place more or less automatically, and CLIL classrooms are generally regarded by teachers and syllabus developers as subject classrooms with a focus on meaning" (Ibidem) indicates that the student's mother tongue is always at play in the attempt to convey meaning.

The question types mostly used throughout the units of the history textbooks document the distinctiveness of the English-speaking civilization by multiple choice, matching, and odd-one-out. They target the newly acquired knowledge of history (and, for that matter, of literature or culture). As a matter of fact, they are supposed to foster cultural communication within the community of English speakers to be found in the classroom rather than across the boundaries of the bilingual setup of CLIL. For example, the reading section of the unit on "The Longest Reign. The Victorians" (Ronder \& Thompson, 2012: 42) is a case in point of pre-use evaluation. At odds with the above statement, the pre-reading stage involves debating on "your nation" (Ibidem, my emphasis). The next two questions focus on the same other nation as well. Namely, the students are asked: "Did everyone in the country benefit at this time?" and "Who was (were) the most important leader(s)?" (Ibidem). The black and white pictures of the urban poor and the image of Queen Victoria, next to these questions, give a glimpse into the world of Victorian Britain. Furthermore, there is emphasis on the contrastive study of English'your language' vocabulary.

Do you know any words from your language which have entered English? If so, what are they? What about English words in your language?

Discussion: Should we try to protect our language from foreign 'imports' like this, or is it better to be open, like English is, to words from other languages. (Idem, 59)

The same collocation (i.e. "your language") occurs throughout the textbook. The openness of English to foreign words is likely to set the agenda for students. The activity types commonly used for teaching history are the same with the ones suitable for CLIL. The "topic development" (Idem, 45-69) and the "extension activities" (Idem, 46-47) of the unit are designed for supporting written and oral production. They look back on the reading activity and on the findings of reading with a purpose. Everything leads to making inferences and critical reading. The students find themselves in self and peer-evaluation circumstances each time they have to answer questions about their mother tongue. The post-use evaluation has the role of awareness-raising and, one way or another, the self-identification patterns of the English-speaker fall back on his/her previous experiences and Romanian national culture. Learners need to know the differences between their language and history and those of Great Britain.

Queen Victoria wore black for 40 years. Write a short essay about wearing black.

Include the following:

- who wears black in your country and why

- the meaning of black clothes in your culture

- whether you ever wear black, when and why

- how black makes you feel

- whether you think we need to change our ideas about black (Idem, 47)

Whether they change or feel the need to change our ideas is for the teacher-controlled feedback to decide. The information transfer achieved while reading, but also once the follow-up started, is judged against the benchmark of meaning focus activities. As it happens, students come to understand and appreciate the benefits of word loans from English: 9/11 (attacks), colonialism, information technology (IT).

CHB makes the point that everything one knows about the Victorian era boils down to the following conclusion: "Even though Queen Victoria had very little real power, her moral influence was enormous, and she ruled over the largest empire in the history of the world" (Brodey, 2007: 70). The self-aggrandizing theme of the empire fits in with the cause and effect narrative of history. The primary 
goal of the text is to emphasize the 'us versus them' frame of reference, which is always at hand in mainstream history writing. The students are told how the torch of greatness passed from the Romans to Britons (and, eventually, to America). It makes explicit the difference between the study of foreign languages and the late $20^{\text {th }}$ century study of foreign cultures, new disciplines that do not have the tradition of language learning. Namely, the "distinction between an 'insider' and an 'outsider' perspective is one of the key differences between the study of cultures linked to foreign language learning and the interdisciplinary field known as Cultural Studies" (Bassnett, 2014: xviii). Historyteaching in English language classes makes the point that the English-speaking world has a past that was not shared by the Romanian people. They are outside the course of English/British/American history and get to vicariously experience the meaning of greatness in history textbooks, irrespective of the language used to record the nation-centric account of the past. The caption beneath the picture of Queen Victoria reads: "the symbol of Britain during her century of greatness" (Brodey, 2007: 70). Imperialism, explained as the last side effect of "little England" (Ibidem) becoming Great Britain, is the key word of the lesson. Whenever open questions are asked, they prompt revealing answers, elicited by otherwise unassuming instances of higher order thinking skills. Hypothesising, reasoning, and evaluating come across as an attempt to place the local sense of self-identification in the context of the prestige culture whose language students are asked to learn.

The purpose of history-related textbooks is to convey what the past was like, and the way it shaped the present, rather than to help with how to teach history, not to mention English.

\subsection{Literature-related textbooks}

I find that two teacher's books, rather than the textbooks themselves, disclose some of the aspects that delineate the intractable issue of teaching language through literature. Words, Words, Words (Allen et al., 2003) and Pathways to Literature (Evans \& Dooley, 2014) serve to highlight the equally (un)favourable, yet not mutually exclusive, alternatives on the mother tongue use in teaching EFL as well. Various narrative texts have long been linked to foreign language acquisition, which is further proof that literature might be an effective teaching aid. They have always found themselves in competition with diagrams, visuals and, lately, on-screen animation. Overall, they boil down roughly to the same patterns that convey historical meanings to young learners of English. However, something sets apart literature-related books from the distinctly factual rhetoric of history textbooks. Storytelling is less concerned with myth making and obviously less apprehensive about the meaning of the past. Consequently, the highly individual character of the nation is relegated to the background of the story. This is definitely not the case with the case studies and reports of history lessons. Such source materials quote the worldview of 'founding fathers', who turn out to be very keen on the "awe-inspiring" (Harmer, 2007: 13) rise of English as a lingua franca.

The literature-related textbooks favour the morality lesson. Rather than approaching the topics at hand in a neutral manner, the young learners of English are exposed to a value-laden account of the Anglo-American worldview. The story of canonical literature aims to instruct the students in the art of moral living. The message of the most novels under scrutiny reveals that foreign language learning is supposed to build the citizens of tomorrow. The materials of the EFL textbook advocate for the values of family life, respect for one's elders or Christian faith, etc. These and other attributes of an ideal society, in the making at the time most literary masterpieces of classic English literature were released, turned out to be particularly resilient in English teaching. I have in mind the novel of Thomas Hardy, Tess D'Urbervilles: A Pure Woman Faithfully Presented in Words, Words, Words (Allen et al., 2003), as well as Oscar Wilde's The Picture of Dorian Gray in Pathways to Literature (Evans \& Dooley, 2014). They are cases in point of what is perceived as a late $19^{\text {th }}$ century cautionary tale. By association, the pursuit of beauty and moral perfection seem to rank high on the agenda of the $21^{\text {st }}$ century literature lesson in EFL classes. What is more, the distinguished human valour of heroes is recorded in the language of literary description and characterization, which now reach an audience often uncomfortable with the lofty style of the popular fiction the public fell for more than a hundred years ago. It feels safe to say that the moralizing address to the reader does not sit well with most English students. Yet, the two novels seem to be a highly appreciated rite of passage for them, rather than rite-of-passage books in themselves. The ready availability of discourses that memorialize the momentous events of the past 
in the mainstream of public life makes the rhetoric of history much more user friendly than that of the novel genre.

Coming back to our examples, teachers are instructed to point out notions of "the corruption of [his] soul"; for the benefit of their students, they are expected to argue that Dorian "is falling apart as the result of his evil ways" and that he "is similar to Faust because both men want something that they can't have normally" (Evans \& Dooley, 2014: 54). The interplay between outer beauty and moral ugliness should help remind the reader of civic duties and the greater good of the community. Obviously, the teacher's book has to come up with a number of suggested answers. They all get one message across, any which way they can: the challenge to the senses posed by good looks needs to be internalized by the pupils. They dwell on a language that "should include such adjectives as: innocent, pious, simple, fragile, sensitive" (Allen et al., 2003: 136).The aim is to dispel the notion that any hint of glamour might be connected to the big questions of life, i.e. "eternal time", "human existence" or "human knowledge" (Ibidem). The positive feed-back from the students is the last consequence of the melodrama dealing with the so-called 'symbolic connotations of sacrifice' as well as with the anxiety that imbues the schedule of class activities. As compared to history-related textbooks, the syllabus centred on the pre- and early- $20^{\text {th }}$ century novel genre is a useful nexus for the interdisciplinarity required by consuming popular culture. More than the factual rhetoric of history, the fictional narrative accommodates ambiguity in a manner that is familiar to present day TV-viewers, film-goers and everyday internet users. However, the skills needed to decode literary texts and, importantly, to respond to them as anticipated by teachers, involve more than the customary reading for information technique, customarily employed in the digital environment. What is difficult to pass on to the new learners of English already familiar with the language of e-publishing is the tradition of "slow and meditative possession of a book" (Birkerts, 2006: 146) that the reading of canonical novels seems to entail.

Each of the above-mentioned novels makes for a good topic of class debate on morality codes, gender roles, and responsible conduct in society. To cut a long story short, the good-versus-evil plot of literature replaces the us-versus-them storytelling pattern of history.

\section{An intractable choice: which language to use in order to teach the other language}

Judging from the above-mentioned textbooks, the need to hold teachers to a certain reliable standard when it comes to the use value of the mother tongue in teaching English is plain to see. Rather than encouraging subtle reasoning, the English teacher has to consider the question of identity whenever (s)he faces his/her students. More often than not, recognizing the one who produces discourse as being (close to) a native-like English speaker (or not) is what makes the difference in Romanian classrooms. Teaching English as an intercultural language is what content English integrated learning seems to be after. Most new textbooks now in use in Romania have CLIL sections that are to be found in every learning unit. The aim is to provide the teacher with what it takes to give lessons that do not have a distinctive national character, in accordance with an understanding of CLIL as intercultural communication. Specifically, the CLIL sections of the EFL textbooks tend to consider topical issues, such as the global multicultural society, the climate change, or renewable energy. A neutral, scientific language that approaches the contentious issue of identity in terms of cultural heritage rather than ethnic identity is on display. The specialized discourse of tourism and information technology takes the place of the narrative centred on the history of the nation and on the morality tale of the novel, respectively.

All the textbooks previously mentioned prompt students and teachers to delve further into the topic of the English-speaking civilization as a means to an end. The challenge is to assess the degree to which "language pedagogy supports the spread and promotion of the language, to the political, economic, military, and cultural pressures that propel it forward" (Phillipson, 1992: 2). Although the teaching of a foreign language starts small, all big things start like this in the classrooms of the nation. A survey among 40 primary and secondary school teachers, based in the North-East of Romania (i.e. in the counties of Suceava, Neamț and Botoșani), about their experience of teaching English found that the place of Romanian culture in the EFL classes is quite important ${ }^{4}$.

\footnotetext{
4 The survey was carried out on 28 May 2016; it was administered as a post-test to all participating English teachers in the "First Annual Symposium on English Language Teaching and Learning", held by The Department of Foreign Studies (Ștefan cel Mare University of Suceava) and Silvia Manoliu Association for Anglophone
} 
The reasons for language teaching in a particular situation depend on factors that cannot be summed up adequately just as 'communication' or as 'foreign' versus 'second' language teaching. Even if teachers themselves are powerless to change such reasons, an understanding of the varying roles for language teaching in different societies and for different individuals is an important aid to teaching. (Cook, 2016: 228)

Most respondents played down the need to speak another language than English in the EFL class, even if they teach early learners a new language. The Romanian language and culture rarely ranked as "very important", although in no less than 25 inquiry forms "important" is the answer to the question "what is the place of Romanian culture in EFL classes?"; 6 interviewees said that the place of Romanian is "very important"; only 5 of them found that it is "not important". Importantly, none ticked the box for "it should go unmentioned". The question "how often do you discuss Romanian-related issues in your English classes" brought the debate back to practical issues. The answers mirror the trend of the previous ones, with 28 of them stating that such issues are tackled "once a week" (i.e. 16) or "in almost every lesson" (i.e. 12); 8 respondents said they rarely (once a month) touch on Romanian topics, while only one answer is "never" 26 attendees of the regional symposium on EFL teaching felt that "students are more motivated to learn EFL with their native culture in focus" (13 answered "yes, with significant difference" and the other half "yes, but not much difference"); 5 said that there is "no difference" whereas other 5 teachers confessed not knowing whether it makes a difference ("don't know") 7 . By a large margin, the United Kingdom is the main reference point for primary and secondary school English teachers in the North-East of Romania: 30 questionnaires placed the UK first among the world's English-speaking countries in relation to teaching notions of literature, history, geography and popular culture that come in handy while teaching English ${ }^{8}$. The question "which (English-speaking) country do you mostly focus on?" had only 1 answer that placed the US first and 2 that gave the two countries equal weight ${ }^{9}$.

As an indication of what is likely to happen from now on in the public schools of Romania, the survey obviously lacks scientific rigour. Nevertheless, it adds depth to possible explanations of how the mother tongue and the national culture are resources readily available in the formal setting of the EFL class. If not something else, it offers flavour in order to build further on the methodology of English teaching. Ultimately, the questionnaire helps to examine most of the views on the use-value of Romanian in the teaching of English I have expressed so far.

Coupled with the language policy of the EU, English has lately become the language of academic research in Romanian higher education, not only the most studied foreign language in postcommunist Romania. Everything seems to start in Romanian secondary schools. Coming back to the Romanian higher education, research in universities is currently being conducted in other languages than Romanian, i.e. mostly in English. In the long run, this is effective proof that English is spoken and written at the expense of specialized Romanian language. Moreover, this threatens the use-value of the Romanian language as the language of research in Romanian universities. Consequently, it is conceivable that Romanian is going to be increasingly relegated to private life and aesthetic endeavours. Despite the fact that English is increasingly viewed as the language of science, for a vast majority of Romanian speakers nothing much has changed since the country's intelligentsia resorted to foreign languages (i.e. French and German) in order to make the country modern. The choice was a political statement then as much as it is now. The assumption is that the best interest of the Romanian people is

\footnotetext{
Studies. The respondents had the time to read through the survey prior to answering questions. This was an 8 item questionnaire that had Likert items, open response questions and multiple choice ones. The final 2 items targeted background teacher information and asked for the name of the textbooks in use at the time in the public schools of Suceava, Neamț and Botoșani counties.

54 respondents did not give a definite answer, although one of them said "it could be used/mentioned as long as it serves to teach a new language".

63 respondents did not answer this question.

74 respondents did not answer this question.

${ }^{8}$ The English study programme of the Ștefan cel Mare University has everything to do with the answer: a majority of those who took the survey are Suceava graduates. It is apparent that the money brought by the British Council to Suceava County, back in the 2000s, was money well spent.

${ }^{9} 7$ respondents did not answer this question.
} 
served by Westernizing the nation, hence the focus on continental languages and, ever since the fall of the communist regime, on English. The trend for more intercultural lessons, which debate on a worldwide community of English-speaking citizens, is on the rise, yet the morality lessons associated with literature and history seem to be here to stay.

The methodological demand to enforce an English only policy in the EFL class is anticipated by all teachers as they face questions about their conduct while in class. Most likely, they keep it in mind and stick to English, if the circumstances permit. However, they seem keenly aware that even bilingual pupils are bound to bring into play learning motivations steeped in their own sense of place and identity. At odds with the mainstream 'English-only mantra' of the formal education setting, the average student of English looks at his/her mother tongue for better understanding the British and the American culture and identity. The restraint interferes with the freedom of teachers to act as they would see fit in particular conditions; doing what the norm calls for leaves most of them consumed with a sense of anxiety. The practice of translation, mostly of historical and literary texts alongside authentic materials, alleviates much of the angst caused by the predicament of English teachers with regard to the use-value of the mother tongue in EFL classes, which should also explain the resilience of the narrative text as a teaching resource in most textbooks.

Conclusively, English is still a foreign language in post-communist Romania, rather than the international language that local speakers might be tempted to use in order to address everyday big and small challenges.

\section{Works Cited}

Archer, M. S. 1996. Culture and Agency. The place of culture in social theory, Cambridge University Press.

Allen, D. R., Roberts, R. J., Tierney, J., Whiteside, G., Wrenn. C., Malgaretti, F. G. 2003. Words Words Words. A History and Anthology of Literatures in English. The 20th Century Literatures in English, Milan: La Spiga languages.

Bassnett, S. 2014. "Introduction: Studying British Cultures” In: Bassnett, S. (ed), Studying British Cultures. An Introduction, London and New York: Routledge, xiii-xxiv.

Bentley, K. 2010. The TKT Teaching Knowledge Test Course CLIL Module Content and Language Integrated Module, Cambridge: Cambridge University Press.

Billig, M. 1995. Banal Nationalism, London, Thousand Oaks, New Delhi: SAGE Publications.

Birkerts, S. 2006. The Gutenberg Elegies: The Fate of Reading in an Electronic Age, New York: Faber and Faber.

Brodey, K. 2007. A Concise History of Britain from its Beginnings to The Present Day, Recanati: ELI - Modern languages.

Clark, A. 2006. Teaching the Nation. Politics and Pedagogy in Australian History, Carlton: Melbourne University Press.

Cook, V. 2016. Second Language Learning and Language Teaching. Fifth Edition, New York and London: Routledge.

Dalton-Puffer, C., Nikula, T. \& Smit, U. 2010. "Charting policies, premises and research on content and language integrated learning” In: Dalton-Puffer, C., Nikula, T. \& Smit, U. (eds.), Language Use and Language Learning in CLIL Classrooms, Amsterdam / Philadelphia: John Benjamins Publishing Company, 1-19.

Edge, J. 1989. Mistakes and Correction, Harlow: Longman.

Evans, V., Dooley, J. 2014. Pathways to Literature, Teacher's Book, Newbury: Express Publishing.

Evans, V., Dooley, J. 2014. On Screen, Teacher's Book, Newbury: Express Publishing.

Harmer, J. 2007. The Practice of English Language Teaching, Fourth Edition, Harlow, England: Pearson Longman.

Hedge, T. 2000. Teaching and Learning in the Language Classroom. A guide to current ideas about the theory and practice of English language teaching, Oxford University Press.

Heine, L. (2010). Problem Solving in a Foreign Language, Berlin/New York: De Gruyter Mouton.

Hinnov E. M., Harris L., Rosenblum L. M., (eds.). 2013. Communal Modernisms. Teaching Twentieth-Century Literature and Culture in the Twenty-First-Century Classroom, Basingstoke and New York: Palgrave Macmillan.

Marsh, D. 2009. “Introduction: Culture, Education \& Content and Language Integrated Learning.” In: Carrió Pastor, (ed.), Content and Language Integrated Learning: Cultural Diversity, Frankfurt: Peter Lang, 1130 .

Masuhara, H., Tomlinson, B. 2008. "Materials for General English” In: Tomlinson, B. (ed), English Language Learning Materials. A Critical Review, London and New York: Continuum. 
O’Connell, F. 2009. "The BritLit Story. A brief history and theory.” In: BritLit: USING LITERATURE IN EFL CLASSROOMS, London: British Council, 11-16.

Phillips, R. 2000. "Government policies, the State and the teaching of history” In: Arthur, J. and Phillips, R. (eds.), Issues in History Teaching, London and New York: Routledge, 10-23.

Phillipson, R. 1992. Linguistic Imperialism, Oxford, New York: Oxford University Press.

Ronder, D., Thompson, P. 2012. Past Simple. Learning English through History, Reading: Garnet Education.

Scholes, R. 1999. The Rise and Fall of English: Reconstructing English as a Discipline. New Haven: Yale University Press.

Scholes, R. 2011. The English Curriculum after the Fall: From Literature to Textuality. Iowa City: University of Iowa Press.

Schwarz, D. R. 2008. In Defense of Reading: Teaching Literature in the Twenty-First Century, Malden, MA., Oxford, Chichester: Wiley-Blackwell.

Spring, J. 2016. American Education, 17 ${ }^{\text {th }}$ Edition, New York and London: Routledge.

Thornbury, S. 2006. An A-Z of ELT, Oxford: Macmillan.

Tomlinson, B. 2003. Developing Materials for Language Teaching, London and New York: Continuum.

Tomlinson, B. (2008), “Language Acquisition and Language Learning Materials.” In: Tomlinson, B. (ed), English Language Learning Materials. A Critical Review, London and New York: Continuum, 3-13. 